\title{
Bush is a threat to US stem-cell research
}

Angst is growing within America's biomedical research community that the new George W. Bush administration will cut off money for fetal-tissue and stem-cell research because of its views on abortion. Newly inaugurated, Bush wasted no time injecting himself into the controversial debate by once again declaring his opposition to government funding of medical research

that uses fetal tissue obtained from abortions, or stem cells derived from embryos that are later destroyed.

Although he did not say he would overturn the current policy that allows such funding, he reiterated statements he had made during the 2000 presidential campaign, saying, "I do not support research from aborted fetuses." Meanwhile, Bush's new secretary of Health and Human Services, former Wisconsin Governor Tommy Thompson-an abortion foe-has in the past praised stem-cell research, particularly the University of Wisconsin scientists who were among the first to grow stem cells in large quantities. But Thompson is now hinting that he might have to change his views and review the government's policy towards stem-cell research.

In his first days in office in 1993, President Clinton overturned a ban on federal funding for fetal-tissue research introduced by Ronald Reagan. Since that time, the government has spent $\$ 124$ million on fetal-tissue research. Last year, the $\mathrm{NIH}$ (National Institutes of Health) was awarded $\$ 20$ million in grants for such research, and hopes to begin funding the first grants for embryonic stem cell research later this year.

At the time that Clinton overturned the fetal-tissue ban, Congress explicitly prohibited the executive branch from stopping fetal-tissue transplantation research. This would make it extremely difficult for Bush to stop all fetal-tissue research money, although he could issue an Executive Order barring stem-cell research specifically.

Scientists are unhappy at the thought that adult stem cells would become the only research alternative. "You can't expand these cells-they can't grow in large numbers," says John Gearhart of Johns Hopkins University. "These [adult] cells don't have the same plasticity or broad range of potential. Also, we don't know the impact the aging process would have on these cells. And they are very few in number-you would have to collect a lot of cells. Finally, if you have a genetic-based disease, the [adult] stem cells would have the same gene defect. With embryonic cells, we know we can manipulate them genetically." Johns Hopkins
University has received a $\$ 58.5$ million donation to create a new institute focused on stern-cll research.

Scientists are also worried that inroads already gained will be lost, and that the pace of stem-cell research will slow if funds for embryo research are eliminated. Curt Freed, a researcher at the University of Colorado Health Sciences Center-who is due to report encouraging results with fetal-tissue transplants in patients with advanced Parkinson disease in the New England Journal of Medicine-calls the NIH "the only source of funds for high quality controlled clinical trials. If there is no $\mathrm{NIH}$ funding, then research would revert to anecdotes, and the possibility of exaggerated evaluation of transplantation outcome." Gearhart agrees, adding that without federal funding, "the research won't move as rapidly."

Marlene Cimons, Washington, DC

\section{Election year boost for Australian R\&D}

Australia's research community has acknowledged an Aus $\$ 2.9$ billion (US $\$ 1.6$ billion) five-year plan to boost science and technology as a welcome but belated attempt to redress years of neglect.

Prime Minister John Howard, who faces a general election this year, is claiming that the package to boost research grants, improve university infrastructure and restore $R \& D$ investment incentives was "the largest commitment to innovation ever made by an Australian government."

Over the next five years the government has pledged to double Australian Research Council (ARC) competitive grants to $\$ 736$ million, increase university places and double postdoctoral fellowships, provide $\$ 246$ million for upgrading tertiary research infrastructure, restore R\&D tax concessions, boost start-up funds for commercialization of research ( $\$ 535$ million) and expand the Cooperative Research Centre industry partnership program (\$227 million). The money follows a doubling of the budget for the National Health and Medical Research Council two years ago (Nature Med., 5, 598; 1999).

But the response from the scientific community is divided. A key lobbyist for the package, ARC chair Vicki Sara, is predicting that it will help Australia to lead the world in strategic areas including molecular biology and quantum computing. And the Federation of Australian Science and Technological Societies (FASTS) suggests the package could reverse the technology-driven decline in the Australian dollar.

However, some say the initiative, called 'Backing Australia's Ability,' does little more than "play catch-up," and although the government may gain electoral kudos from the announcement, the bulk of funds will not be available until 2003.

The Australian Society for Medical Research (ASMR) believes that the injection of funds will bring the country up to par rather than confer any special advantage by the end of five years. "It would be nice if there was more money available in the earlier stages," ASMR president Peter O'Loughlin commented.

FASTS policy chairman Ken Baldwin says that the lukewarm reception for the package "partly reflects its long gestation" and warns that more reforms are needed. O'Loughlin agrees with FASTS there has been a "sea change" forced by the massive investment of fast-growing economies such as Singapore, Canada and Ireland in science and technology. Rada Rouse, Brisbane 